\title{
Atypical Lymphocyte Count
}

National Cancer Institute

\section{Source}

National Cancer Institute. Atypical Lymphocyte Count. NCI Thesaurus. Code C64818.

The determination of the number of atypical lymphocytes in a blood sample. 